\title{
POTENSI REGENERASI DAN PENYEBARAN Shorea balangeran (Korth.) Burck DI SUMBER BENIH SAKA KAJANG, KALIMANTAN TENGAH
}

(Regeneration Potential and Distribution of Shorea balangeran (Korth.) Burck in Saka Kajang Seed Stand, Central Kalimantan)

Oleh/By:

\section{Tri Atmoko}

Balai Penelitian Teknologi Konservasi Sumber Daya Alam

Jl. Soekarno-Hatta, Km. 38 Samboja; Telp. (0542) 7217663; Fax. (0542) 7217665; Po. Box. 578

Balikpapan, Kalimantan Timur

e-mail: triad_164@yahoo.com

\begin{abstract}
Study on regeneration potential and distribution of Shorea balangeran (Korth.) Burck was conducted in Saka Kajang seed stand, Central Kalimantan. The purpose of this study was to obtain information on regeneration potential and distribution pattern of $\mathrm{S}$. balangeran. The study was conducted 12 plots that ware arranged in purposive sampling. The method used was vegetation analysis in plotted strips. Data on tree distribution pattern was obtained by mapping all S. balangeran with $\mathrm{dbh}>10 \mathrm{~cm}$ and recording their phenotype. The results showed that there were 57 species that consist of 33 generas and 23 families. S. balangeran dominates vegetation at stages of tree, pole and seedling, while at the sapling stage of vegetation dominated by Macaranga bancana (Miq.) Muell. Arg. 2736 S. balangeran trees with dbh $>35 \mathrm{~cm}$ were found spread contiquously. The density of trees with medium diameter class $(30-39,9 \mathrm{~cm}, 40-49,9 \mathrm{~cm}$ and 50-59,9 cm) was high (3,86 trees/ha, 4,57 trees/ha and 3,29 trees/ha, respectively). On average the conopy occupy the stratum $C$.
\end{abstract}

Keywords: species composition, regeneration potential, distribution, phenotype, Shorea balangeran (Korth.) Burck

\begin{abstract}
ABSTRAK
Penelitian potensi regenerasi dan penyebaran Shorea balangeran (Korth.) Burck dilakukan di Tegakan Benih Teridentifikasi (TBI) Saka Kajang, Kalimantan Tengah. Penelitian bertujuan untuk mengetahui potensi regenerasi dan penyebaran S. balangeran. Penelitian dilakukan dengan analisis vegetasi metode jalur berpetak. Petak yang dibuat sebanyak 12 yang ditempatkan secara purposive sampling. Sedangkan data penyebaran pohon diperoleh dengan memetakan seluruh pohon $S$. balangeran $\mathrm{dbh}>10 \mathrm{~cm}$ dan mencatat kondisi fenotifnya. Hasil penelitian
\end{abstract}


menunjukkan bahwa komposisi vegetasi di TBI Saka Kajang terdiri dari 57 jenis, termasuk dalam 33 marga dan 23 suku. Vegetasi tingkat pohon, tiang dan semai didominasi oleh $S$. balangeran, sedangkan tingkat pancang didominasi jenis Macaranga bancana (Miq.) Muell. Arg. Pohon S. balangeran dijumpai sebanyak 273 pohon, sebagian besar berdiameter batang $>35 \mathrm{~cm}$ dan tumbuh saling berdekatan. Pohon berdiameter menengah $(30-39,9 \mathrm{~cm}, 40-49,9 \mathrm{~cm}$ dan 50-59.9 cm) mempunyai kerapatan yang tinggi (3,86 pohon/ha, 4,57 pohon/ha dan 3,29 pohon/ha) dan rata-rata tajuknya menempati lapisan (stratum) $\mathrm{C}$.

\section{Kata Kunci: Komposisi jenis, potensi regenerasi, penyebaran, fenotif, Shorea balangeran (Korth.) Burck}

\section{PENDAHULUAN}

Shorea balangeran (Korth.) Burk adalah salah satu jenis dari suku Dipterocarpaceae yang secara alami tumbuh pada daerah rawa gambut. Kayu jenis ini memiliki nilai ekonomi yang tinggi, karena memiliki kelas awet II dan kelas kuat II (Martawijaya dan Kartasujana, 1977). Seiring dengan kegiatan eksploitasi yang tidak terkendali untuk memenuhi permintaan pasar, menyebabkan jenis ini semakin langka dan sulit dijumpai. Menurut tingkat kelangkaannya maka S. balangeran masuk dalam kategori critically endangered menurut IUCN, sehingga diperlukan upaya pengembangan jenis tersebut untuk kegitan rehabilitasi maupun pembangunan hutan tanaman produksi.

Dalam upaya pembangunan hutan tanaman, diperlukan ketersediaan benih dan bibit yang berkualitas dan dalam jumlah yang mencukupi. Benih yang berkualitas dapat diperoleh dari sumber benih yang dikelola dengan baik. Menurut database sumber benih Balai Perbenihan Tanaman Hutan (BPTH) Kalimantan tahun 2008, di Kalimantan tercatat sebanyak 30 tegakan sumber benih Dipterocarpaceae dengan luas mencapai $1.871,45$ ha. Namun demikian penyediaan benih jenis Dipterocarpaceae masih menjadi masalah sampai saat ini. Benih Dipterocarpaceae bersifat rekalsitran sehingga tidak dapat disimpan dalam waktu lama, selain itu periode pembungaan dan pembuahan yang tidak menentu, yaitu berkisar antara 4- 5 tahun sekali (Yasman, 1994) atau 5-13 tahun sekali (Smits, 1986). Hal ini menyebabkan ketersediaan benih dari biji tidak tersedia setiap tahun. Oleh karena itu penunjukkan dan pengelolaan tegakan sumber benih sangat penting untuk dilakukan.

Tegakan benih teridentifikasi (TBI) adalah tegakan alam atau tanaman dengan kualitas ratarata yang digunakan untuk menghasilkan benih dan lokasinya dapat teridentifikasi dengan tepat (Ditjen RLPS, 2004). Dalam penunjukannya areal TBI harus mempunyai kualitas tegakan yang baik dengan dominansi oleh jenis-jenis target dan jumlah pohon induk yang mencukupi. Sumber benih yang dikelola dengan baik diharapkan dapat memenuhi kebutuhan benih, baik secara kualitas 
maupun kuantitasnya.

Sumber benih Saka Kajang adalah TBI jenis $S$. balangeran yang sudah disertifikasi, namun belum dilakukan pengelolaan dengan baik bahkan belum diketahui potensi dan tingkat dominasi jenis targetnya. Penelitian ini bertujuan untuk mengetahu potensi dan tingkat regenerasi S. balangeran sehingga dapat menjadi dasar untuk pengelolaan sumber benih kedepannya.

\section{METODOLOGI}

\section{A. Waktu dan Lokasi}

Penelitian dilakukan pada bulan April 2009 di sumber benih balangeran Saka Kajang, Kecamatan Jabiren Raya, Kabupaten Pulang Pisau, Kalimantan Tengah. Secara geografis sumber benih terletak pada koordinat $114^{\circ} 10^{\prime} 20^{\prime \prime}-114^{\circ} 10^{\prime} 50^{\prime \prime}$ BT dan $2^{\circ} 34^{\prime} 30^{\prime \prime}-2^{\circ} 34^{\prime} 60^{\prime \prime}$ LS. Aksesibilitas untuk menuju lokasi TBI Saka Kajang dapat ditempuh dari Banjarbaru ke Kabupaten Pulang Pisau melalui jalan darat sejauh kurang lebih 150 km/4 jam. Dari Pulang Pisau ke Desa Saka Kajang kurang lebih $35 \mathrm{Km} / 1,5$ jam. Sedangkan dari Desa Saka Kajang ke lokasi sumber benih ditempuh dengan jalan kaki dengan jarak kurang lebih $2 \mathrm{~km}$.

Sumber benih Saka Kajang adalah areal seluas 7 ha yang terletak pada dua lokasi yang berdekatan, masing-masing seluas 2 ha dan 5 ha. Sumber benih ini sudah disertifikasi oleh Balai Perbenihan Tanaman Hutan (BPTH) Banjarbaru melalui sertifikat nomor 041/V-BPTH.KAL2/STFK/2005 dan 073/BPTH.KAL-2/STFK/2006 dengan status Tegakan Benih Teridentifikasi (TBI) dan dikelola oleh Koperasi Unit Desa (KUD) Kahimat.

\section{B. Alat dan Bahan}

Alat yang digunakan adalah: kompas, Global Position System (GPSmap 60CSx), altimeter, roll meter, pita meter, kantong plastik, kertas koran dan kertas label. Bahan yang digunakan adalah spiritus dan tegakan pohon $S$. balangeran di TBI Saka Kajang.

\section{Pengumpulan Data}

Pengambilan data dilakukan pada areal seluas 14 ha terdiri dari TBI Saka Kajang I (2 ha), TBI Saka Kajang II (5 ha) dan areal di sekitarnya (7 ha). Pengumpulan data analisis vegetasi menggunakan metode jalur berpetak yang ditempatkan secara purposive sampling. Jalur analisis vegetasi dibuat dengan lebar $20 \mathrm{~m}$ yang di dalamnya terbagi ke dalam petak berukuran $20 \mathrm{~m}$ x $20 \mathrm{~m}$ untuk tingkat pohon, sub-petak $10 \mathrm{~m}$ x $10 \mathrm{~m}$ untuk tingkat tiang, sub-petak $5 \mathrm{~m}$ x $5 \mathrm{~m}$ untuk pancang, dan sub-petak 2 m x 2 m untuk semai. Total petak yang dibuat adalah 12 petak (0,48 ha). Tingkatan vegetasi yang diamati meliputi: tingkat pohon (diameter batang lebih dari $35 \mathrm{~cm}$ ); tingkat tiang (diameter batang $10 \mathrm{~cm}-35 \mathrm{~cm}$ ); tingkat pancang (diameter batang kurang dari $10 \mathrm{~cm}$ dan tinggi 
lebih dari 1,5 m); dan tingkat semai (anakan dan herba dengan tinggi kurang dari 1,5 $\mathrm{m}$ ) (Soerianegara \& Indrawan, 1988).

Seluruh tumbuhan pada tingkat pohon, tiang dan pancang di dalam petak pengamatan diidentifikasi jenisnya, diukur diameter batang dan tingginya, sedangkan tumbuhan pada tingkat semai diidentifikasi jenis dan jumlahnya. Spesimen herbarium dibuat untuk identifikasi jenis lebih lanjut di Herbarium Wanariset Samboja, Kalimantan Timur.

Untuk mengetahui potensi dan penyebaran pohon jenis $S$. balangeran dilakukan inventarisasi seluruh pohon $(\mathrm{dbh} \geq 10 \mathrm{~cm})$ di seluruh areal penelitian dan diukur diameter dan perkiraan tinggi, tinggi bebas cabang, luas tajuk serta titik koordinatnya.

\section{Analisis Data}

Potensi regenerasi $S$. balangeran terhadap jenis lainnya diketahui dengan menghitung frekuensi relatif(FR), Kerapatan relatif(KR) dan dominansi relatif(DR) dan Indeks Nilai Penting (INP) dari masing-masing jenis pada setiap tingkatan vegetasi (Mueller-Dombois and Ellenberg, 1974). Data pohon S. balangeran ditabulasi, disajikan dalam grafik dan dianalisis secara deskriptif. Sedangkan penyebaran pohon dilakukan dengan memetakan posisi pohon pada areal penelitian dengan menggunakan software ArcView 3.3 dan program penunjang MapSource.

\section{HASIL DAN PEMBAHASAN}

\section{A. Kondisi Tegakan}

Hasil pengamatan vegetasi pada TBI Saka Kajang dijumpai 57 jenis tumbuhan, termasuk dalam 33 marga dan 23 suku. Komposisi jenis yang ada di TBI Saka Kajang seperti pada Tabel 1.

Tabel (Table) 1. Komposisi jenis, marga, suku, jumlah individu dan luas bidang dasar pada setiap tingkat vegetasi di TBI Saka Kajang (Composition of species, genera, family, tree individual and basal area in each vegetation level at Saka Kajang seed stand)

\begin{tabular}{|l|c|c|c|c|c|}
\hline $\begin{array}{l}\text { Tingkat vegetasi } \\
\text { (Vegetation stage) }\end{array}$ & $\begin{array}{c}\text { Jumlah } \\
\text { jenis } \\
\text { (Number of } \\
\text { species) }\end{array}$ & $\begin{array}{c}\text { Jumlah } \\
\text { marga } \\
(\text { Number of } \\
\text { genus })\end{array}$ & $\begin{array}{c}\text { Jumlah } \\
\text { suku } \\
\text { (Number } \\
\text { of family })\end{array}$ & $\begin{array}{c}\text { Jumlah } \\
\text { individu } \\
\text { (Number of } \\
\text { individuals) }\end{array}$ & $\begin{array}{c}\text { Bidang Dasar } \\
\text { (Total basal } \\
\text { area })\left(\mathrm{m}^{2}\right)\end{array}$ \\
\hline Pohon (Tree) & 7 & 5 & 5 & 53 & 10,77 \\
\hline Tiang (Pole) & 19 & 14 & 10 & 43 & 1,43 \\
\hline Pancang (Sapling) & 42 & 26 & 18 & 405 & 0,20 \\
\hline Semai (Seedling) & 22 & 18 & 15 & 1.579 & - \\
\hline $\begin{array}{l}\text { Semua jenis (All } \\
\text { species) }\end{array}$ & 56 & 33 & 23 & 2.080 & 12,4 \\
\hline
\end{tabular}


Jumlah jenis pada vegetasi tingkat pohon dan tiang yang ditemukan pada penelitian ini rendah, yaitu hanya 96 individu dari 22 jenis (Tabel 2). Sebagai perbandingan, pada petak seluas 1 ha di hutan rawa gambut bekas terbakar di Taman Nasional Tanjung Puting tercatat sebanyak 1.132 pohon (50 jenis) (Yusuf, 1999). Sedangkan penelitian Saribi dan Riswan (1997) pada petak yang luasnya hampir sama di Arboretum Nyaru Menteng, PT. Bina Samaktha dan PT. Inhutani III Sampit hasil penelitian ini juga menunjukkan jenis yang lebih sedikit.

Tabel (Table) 2. Jumlah jenis, kerapatan dan basal area pada tingkat pohon (diameter $>10 \mathrm{~cm}$ ) di lokasi penelitian dan empat lokasi rawa gambut sekunder lainnya di Kalimantan Tengah (Number of species number, density and basal area of tree stage $>10 \mathrm{~cm}$ dbh) in study site and four other plots of peat swamp forests in Central Kalimantan)

\begin{tabular}{|l|l|l|l|l|l|}
\hline $\begin{array}{l}\text { Lokasi } \\
\text { (Locations) }\end{array}$ & $\begin{array}{l}\text { Ukuran } \\
\text { Plot (Plot } \\
\text { size) (ha) }\end{array}$ & $\begin{array}{l}\text { Jumlah jenis } \\
(\text { Number of } \\
\text { species })\end{array}$ & $\begin{array}{c}\text { Kerapatan } \\
(\text { Tree density) } \\
(\text { ha })\end{array}$ & $\begin{array}{c}\text { Bidang } \\
\text { dasar }(\text { Basal } \\
\text { area })\left(\mathrm{m}^{2} / \mathrm{ha}\right)\end{array}$ & Sumber (Sources) \\
\hline Sk & 0,48 & $22^{*}$ & - & 12,20 & Penelitian ini \\
\hline Tp & 1,0 & 50 & 1132 & 8,19 & Yusuf (1999) \\
\hline $\mathrm{Nm}$ & 0,50 & 49 & 926 & 51,32 & Saribi \& Riswan (1997) \\
\hline In & 0,45 & 37 & 301 & 20,90 & Saribi \& Riswan (1997) \\
\hline Bs & 0,40 & 32 & 251 & 15,21 & Saribi \& Riswan (1997) \\
\hline
\end{tabular}

Keterangan (Remark): Sk= TBI Saka Kajang, Pulang Pisau, Kalimantan Tengah; Bs= PT. Bina Samaktha II, Sampit, Kalimantan Tengah; In= PT. Inhutani III, Sampit, Kalimantan Tengah; Nm= Arboretum Nyaru Menteng, Palangkaraya, Kalimantan Tengah; Tp= TN Tanjung Puting, Kalimantan Tengah; * Jumlah jenis pada tingkat pohon dan tiang.

\section{B. Potensi Generasi}

Salah satu persyaratan suatu tegakan dapat ditunjuk sebagai tegakan benih teridentifikasi adalah komposisi jenisnya harus didominasi oleh jenis yang menjadi target untuk menghasilkan benih. Analisis vegetasi yang dilakukan menunjukkan bahwa vegetasi tingkat pohon, tiang dan semai didominasi oleh $S$. balangeran, sedangkan tingkat pancang didominasi jenis Macaranga bancana, Syzygium sp.1. dan Callopyllum sp.2. Jenis M. bancana yang mendominasi tingkat pancang adalah salah satu jenis pionir yang tumbuh setelah terjadi kebakaran, seperti dilaporkan Phillips (1998) yang menyatakan bahwa Macaranga spp. adalah salah satu jenis pionir di hutan rawa gambut. Jenis $S$. balangeran pada tingkat pancang dijumpai dalam jumlah sedikit dimungkinkan selain karena pengaruh kebakaran juga karena eksplorasi benih dalam bentuk semai yang berlebihan. Sedangkan tingkat pohon dan tiang sudah lebih stabil dalam pertumbuhannya, mendapatkan sinar matahari lebih banyak dan lebih tahan terhadap kebakaran. Hal itu ditunjukkan 
dengan dijumpainya beberapa $S$. balangeran tingkat pohon dan tiang yang batangnya bekas terbakar, namun masih dapat bertahan hidup. Struktur dan komposisi S. balangeran pada terhadap jenis lainnya pada vegetasi tingkat pohon, tiang, pancang dan semai tersaji pada Tabel 3.

Tabel (Table) 3. Lima jenis dominan pada berbagai tingkat vegetasi di TBI Saka Kajang (Top Five dominant trees of different vegetation stage is at Saka Kajang seed stand)

\begin{tabular}{|c|c|c|c|c|c|}
\hline \begin{tabular}{|c|} 
No \\
$($ Number $)$
\end{tabular} & Jenis (Species) & $\begin{array}{l}\text { FR } \\
(\%)\end{array}$ & $\begin{array}{l}\text { KR } \\
(\%)\end{array}$ & $\begin{array}{l}\text { DR } \\
(\%)\end{array}$ & $\begin{array}{l}\text { INP } \\
(\%)\end{array}$ \\
\hline & Tingkat pohon (Trees level) & & & & \\
\hline 1 & Shorea balangeran (Korth.) Burck & 55,000 & 71,70 & 86,90 & 213,60 \\
\hline 2 & Combretocarpus rotundatus (Miq.) Danser & 15,000 & 7,55 & 7,10 & 29,65 \\
\hline 3 & Macaranga bancana (Miq.) Muell. Arg. & 10,000 & 13,21 & 0,94 & 24,15 \\
\hline 4 & Syzygium sp. & 5,000 & 1,89 & 1,48 & 8,36 \\
\hline \multirow[t]{2}{*}{5} & Syzygium lineatum (DC)Merr. \& Perry & 5,000 & 1,89 & 1,48 & 8,36 \\
\hline & Tingkat tiang (Poles level) & & & & \\
\hline 1 & Shorea balangeran (Korth.)Burck & 18,519 & 46,51 & 51,51 & 116,54 \\
\hline 2 & Syzygium sp.1 & 7,407 & 6,98 & 12,56 & 26,94 \\
\hline 3 & Calophyllum sp.2 & 7,407 & 4,65 & 10,06 & 22,12 \\
\hline 4 & Syzygium sp.2 & 7,407 & 4,65 & 2,19 & 14,25 \\
\hline \multirow[t]{2}{*}{5} & Macaranga pruinosa (Miq.) Muell. Arg. & 7,407 & 4,65 & 1,65 & 13,71 \\
\hline & Tingkat Pancang (Saplings stage) & & & & \\
\hline 1 & Macaranga bancana (Miq.) Muell. Arg. & 2,752 & 0,49 & 34,07 & 37,31 \\
\hline 2 & Syzygium sp.1 & 4,587 & 9.88 & 9,19 & 23,66 \\
\hline 3 & Pellacalyx sp.1 & 4,587 & 12,10 & 6,34 & 23,02 \\
\hline 4 & Pternandra rostrata (Cogn.) M.P.Nayar & 8,257 & 7,65 & 6,44 & 22,35 \\
\hline 5 & Macaranga pruinosa (Miq.) Muell. Arg. & 7,339 & 9,38 & 5,45 & 22,17 \\
\hline$\cdots$ & $\cdots$ & $\cdots$ & $\cdots$ & $\cdots$ & $\cdots$ \\
\hline 21 & Shorea balangeran (Korth.) Burck & 1,835 & 0,99 & 0,32 & 3,14 \\
\hline
\end{tabular}




\begin{tabular}{|c|l|c|c|c|c|}
\hline & Tingkat semai (Seedlings stage) & & & & \\
\hline 1 & Shorea balangeran (Korth.) Burck & 20,755 & 92,34 & - & 113,09 \\
\hline 2 & $\begin{array}{l}\text { Melicope luna-ankenda (Gaertn.) T.G. } \\
\text { Hartley }\end{array}$ & 11,321 & 3,23 & - & 14,55 \\
\hline 3 & Syzygium sp. & 9,434 & 0,63 & - & 10,07 \\
\hline 4 & Baccaurea bracteata Muell. Arg. & 7,547 & 0,25 & - & 7,80 \\
\hline 5 & Elaeocarpus griffithii (Wright.) A. Gray & 5,660 & 0,63 & - & 6,29 \\
\hline
\end{tabular}

Keterangan (Remark) $: \mathrm{FR}=$ Frekuensi relatif (relative frequency); $\mathrm{KR}=$ Kerapatan relatif(relative density); $\mathrm{DR}=$ Dominansi relatif (relative dominance); INP = Indeks nilai penting (important value index)

Dalam penelitian jenis dari Suku Dipterocarpaceae yang dijumpai hanya satu jenis saja, yaitu Shorea balangeran. Walaupun sebenarnya jenis Dipterocarpaceae lainnya juga dijumpai di hutan rawa gambut seperti Vatica rassak, Cotylelobium sp., Shorea parvifolia, Shorea teismanii, Vatica pauciflora (Atmoko et al. 2010). Anisoptera marginata, Dryobalanops lanceolata, Dryobalanops rappa, Shorea leprosula, Shorea parvifolia (Siregar dan Sambas, 2000). Newman et al. (1999) menyatakan bahwa penyebaran habitat $S$. balangeran adalah pada lahan rawa gambut sebelah selatan sungai Kapuas, sedangkan di sebelah utara sungai Kapuas jenis ini digantikan dengan jenis Shorea albida. Sebenarnya jenis S. balangeran mempunyai amplitude ekologi yang luas, karena mampu tumbuh dengan baik pada berbagai kondisi tanah dan lingkungan. Jenis ini dapat tumbuh pada lahan terbuka yang kering, lahan gambut sangat dalam dan pada tanah ultisol atau latosol (Daryono, 2006). Omon (1999) melaporkan bahwa jenis ini mampu tumbuh dengan baik pada areal bekas terbakar yang ditumbuhi alang-alang di Kalimantan Timur.

Komposisi jenis menunjukkan bahwa vegetasi tingkat tiang $S$. balangeran memiliki INP yang paling tinggi. Kondisi ini cukup ideal karena nantinya diharapkan dapat menggantikan pohon induk yang mati atau sudah tidak produktif menghasilkan buah. Juliaty et al. (1998) mensyaratkan suatu tegakan sumber benih harus mempunyai umur tegakan yang masih muda, sehingga dapat membentuk tegakan yang baik di masa mendatang dalam periode yang lama dan menghasilkan benih yang banyak, bermutu tinggi baik fisik maupun fisiologik.

Saat penelitian tidak dijumpai pohon induk yang sedang berbunga atau berbuah, namun menjumpai $S$. balangeran tingkat semai dalam jumlah yang melimpah di sekitar pohon induk. Hal tersebut satu indikator bahwa pohon induk sudah pernah berbuah dan menghasilkan benih yang viable. Keberadaan semai ini selain penting peranannya dalam regenerasi tegakan, juga berperan dalam memenuhi kebutuhan bibit dalam bentuk anakan alam, terutama pada saat tidak terjadi musim berbuah. Berdasarkan informasi dari pengelola, melimpahnya tingkat semai di bawah pohon induk pada saat penelitian berasal dari buah yang jatuh pada periode berbuah 4 bulan sebelum 
penelitian dan belum dilakukan pengambilan oleh pengelolanya.

Vegetasi tingkat pancang menunjukkan bahwa nilai INP S.balangeran kecil yaitu pada urutan 21 sebesar 3,14\%. Dilihat dari perbandingan jumlah individu terlihat jenis $S$. balangeran pada tingkat pancang sangat kecil dibandingkan dengan jenis lainnya (Gambar 1). Hal tersebut diakibatkan oleh eksplorasi anakan dalam jumlah yang tinggi, sehingga kesempatan untuk berkembang menjadi tingkat pancang menjadi rendah. Pada tahun sebelumnya KUD Kahimat telah melakukan ekplorasi benih dalam bentuk cabutan alam sebanyak 3 juta bibit (Arpin, komunikasi pribadi). Dalam upaya untuk menjaga sistem regenerasi pohon induk $S$. belangeran perlu dilakukan pembatasan pengambilan benih cabutan alam pada setiap periode berbuahnya.

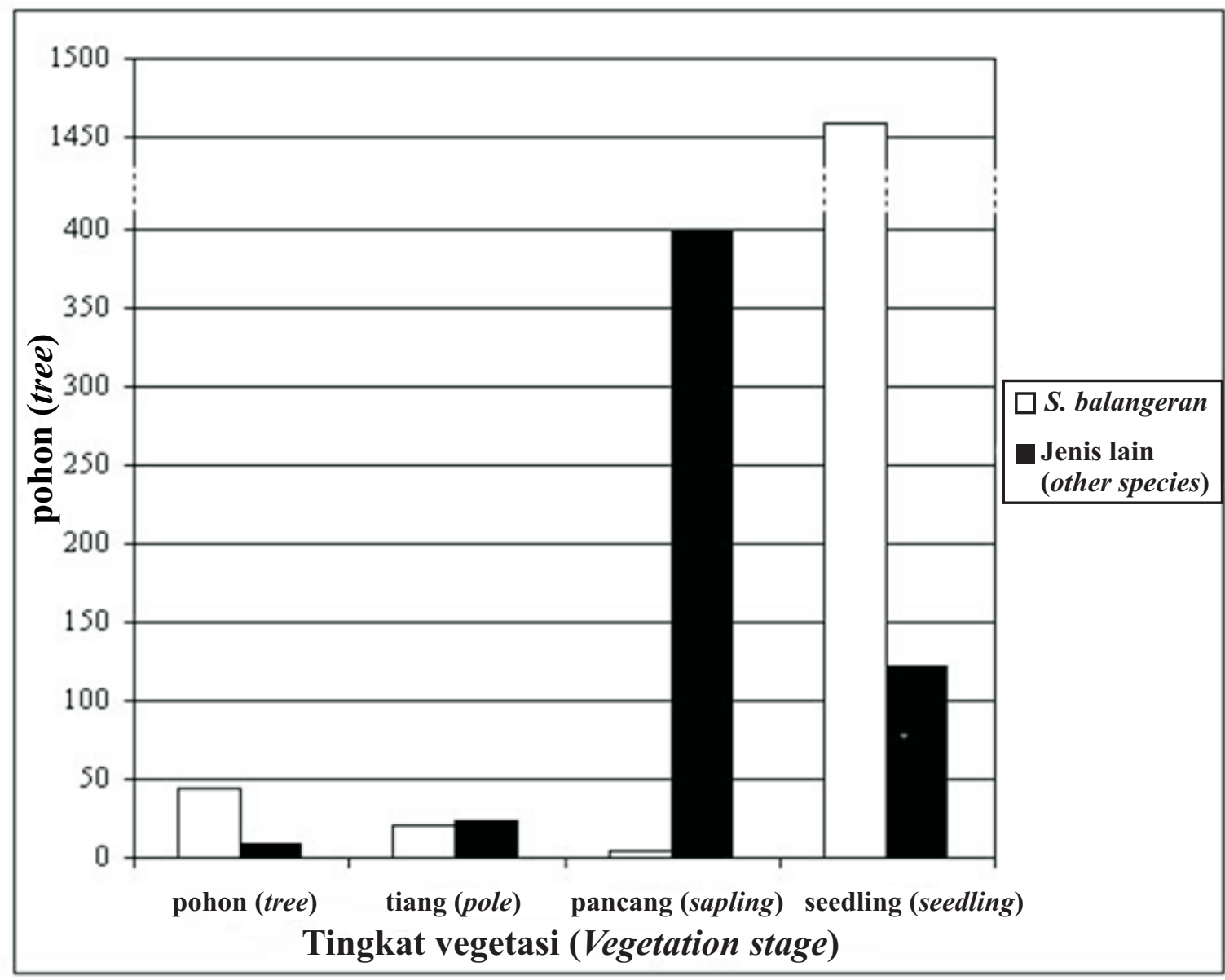

Gambar(Figure) 1. Perbandingan komposisi jumlah individu jenis $S$. balangeran terhadap jenis lainnya pada petak pengamatan (Comparation of individual composition of $\mathrm{S}$. balangeran and other species in observation area) 


\section{Penyebaran S. balangeran}

Pohon S.balangeran di TBI Saka Kajang I dan II cenderung mengelompok dan berdekatan. Jarak antar pohon dan jumlah pohon induk yang ditunjuk sangat penting untuk diperhatikan. Hal itu untuk menghindari terjadinya perkawinan antar individu yang berkerabat dekat (inbreeding) antar pohon induk dan dapat mewakili keragaman genetik yang ada. Menurut Ditjen RLPS (2004) jumlah minimal pohon induk yang diperlukan adalah 25 pohon, namun apabila sulit menemukan 25 pohon maka disarankan tidak kurang dari 10 pohon induk, sedangkan jarak antar pohon induk minimal 50-100 m.

Dari inventarisasi yang dilakukan di lokasi penelitian secara menyeluruh pada pohon S. balangeran (dbh $\geq 10 \mathrm{~cm}$ ), dijumpai sebanyak 273 pohon. Pada TBI Saka Kajang I kerapatan S. balangeran sebesar 38 pohon/ha $(62,6 \% \mathrm{dbh}>35 \mathrm{~cm})$ sedangkan TBI Saka Kajang II kerapatannya sebesar 41 pohon/ha $(81,9 \% \mathrm{dbh}>35 \mathrm{~cm})$. Kondisi tersebut masih memungkinkan untuk mendapatkan pohon induk dengan fenotif yang baik, namun jarak antar pohon induk yang berdekatan menyebabkan kemungkinan besar masih terjadi inbreeding. Sehingga masih diperlukan areal perluasan sumber benih untuk mendapatkan pohon induk yang berfenotif baik dan jarak antar pohon induk yang berjauhan. Oleh karena itu dalam penelitian ini juga dilakukan identifikasi penyebaran pohon $S$. balangeran di lokasi yang berdekatan dengan TBI Saka Kajang II seluas \pm 7 ha. Pemilihan lokasi yang berdekatan dengan sumber benih sebelumnya adalah untuk memudahkan dalam pengelolaannya. Seperti dalam Juliaty et al. (1998) yang menyatakan bahwa keadaan tegakan mudah untuk dikonversi menjadi areal pengumpulan benih. Dari inventarisasi yang dilakukan diperoleh sebanyak 35 pohon S. balangeran dengan jarak yang lebih berjauhan (kerapatan 5 pohon/ha), dari jumlah tersebut 48,5\% diantaranya berdiameter $>35 \mathrm{~cm}$. Penyebarannya S. balangeran pada lokasi penelitian tersaji pada Gambar 2. 


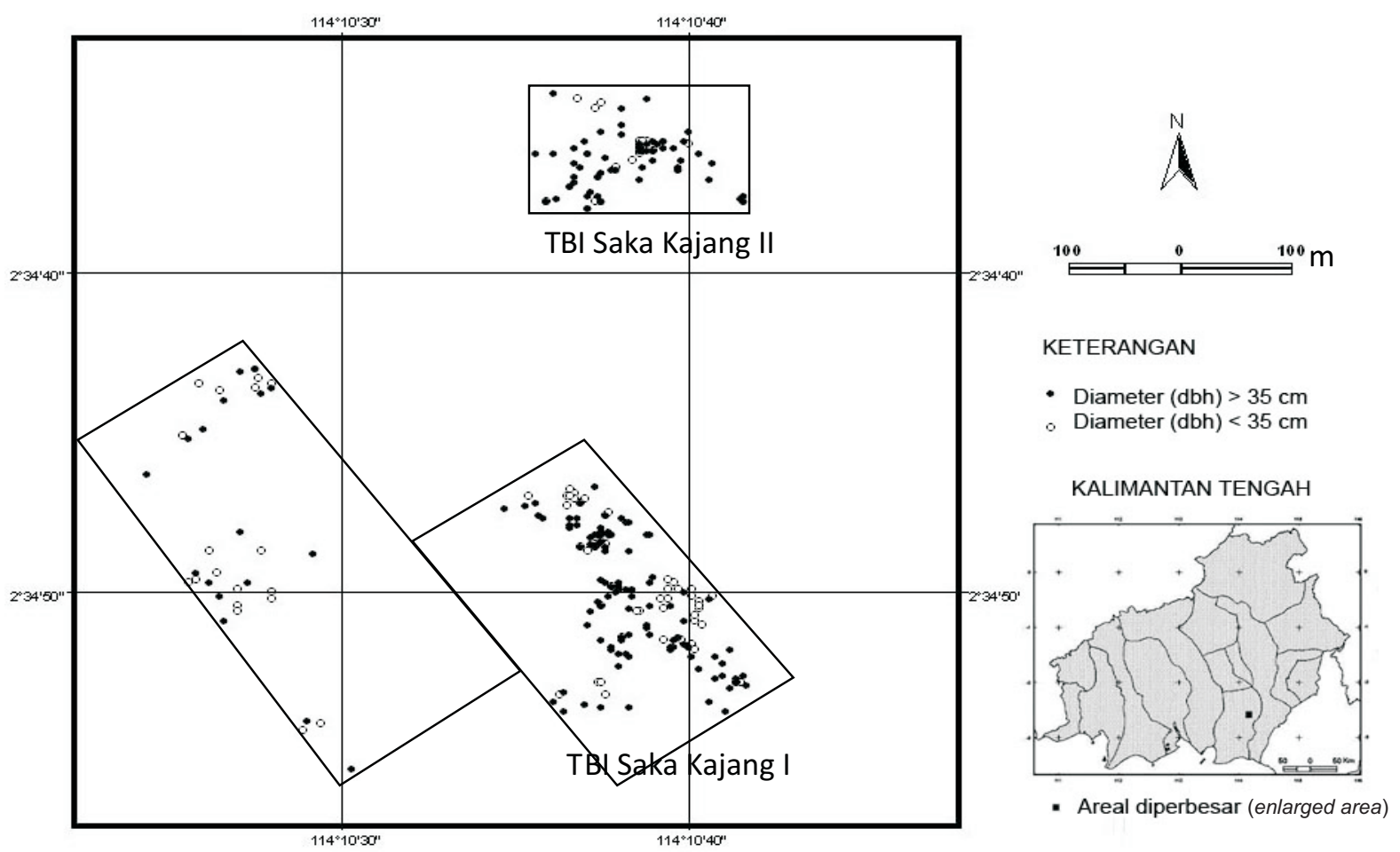

Gambar(Figure)2. Penyebaran Shorea balangeran (diameter $>10 \mathrm{~cm}$ ) di TBI Saka Kajang (Distribution pattern of Shorea balangeran $(\mathrm{dbh}>10 \mathrm{~cm})$ at Saka Kajang seed stand)

Menurut (Ng et al., 2006) penyebaran pohon dipengaruhi oleh beberapa faktor, diantaranya penyebaran biji, topografi, kerapatan jenis, kondisi tempat tumbuh, unsur hara tanah dan kondisi air tanah. Karena penyebaran benih Dipterocarpaceae terjadi oleh angin (anemochory) maka untuk menunjang penyebarannya secara morfologi benih Shorea memiliki sayap yang berkembang dari sepal dan calyx yang membesar (Schmidt, 2000). Pengamatan penulis pada penyebaran biji Anisopthera sp dengan bantuan angin menyebar sejauh lebih dari $0,5 \mathrm{~km}$ dari pohon induknya. Penyebaran biji jenis lain dilaporkan oleh Ashton(1982) yang menyatakan bahwa biji Shorea albida dapat disebarkan angin sejauh $2 \mathrm{~km}$ dari pohon induknya. Selain menyebar dengan bantuan angin, biji S. balangeran di sumber benih Saka Kajang menyebar dengan bantuan air pasang yang pada musim hujan menggenangi hampir seluruh areal tegakan benih.

\section{Kondisi Pohon S. balangeran}

Pada TBI Saka Kajang belum dilakukan penunjukkan pohon induk, padahal sebagai sumber benih yang berasal di hutan alam pemilihan pohon induk berfenotif baik penting untuk dilakukan. Menurut Djamhuri et al. (2007) dalam seleksi pohon induk fenotif yang dinilai adalah tinggi pohon, diameter batang, tinggi batang bebas cabang, bentuk batang, diameter cabang, sudut cabang, ketahanan hama penyakit, kemampuan pemangkasan alami dan produksi buah. Sedangkan Juliaty et al. (1998) mensyaratkan pohon induk mempunyai batang silindris, lurus, batang bebas 
cabang tinggi, diameter besar, tajuk menempati posisi dominan dan kondisi pohon sehat. Dalam penelitian ini yang diidentifikasi adalah semua pohon $S$. balangeran $(\mathrm{dbh} \geq 10 \mathrm{~cm})$, namun tidak dilakukan penilaian fenotif secara mendetail. Informasi fenotif hanya terbatas pada diameter, tinggi total, tinggi bebas cabang dan luas tajuknya (Lampiran 1).

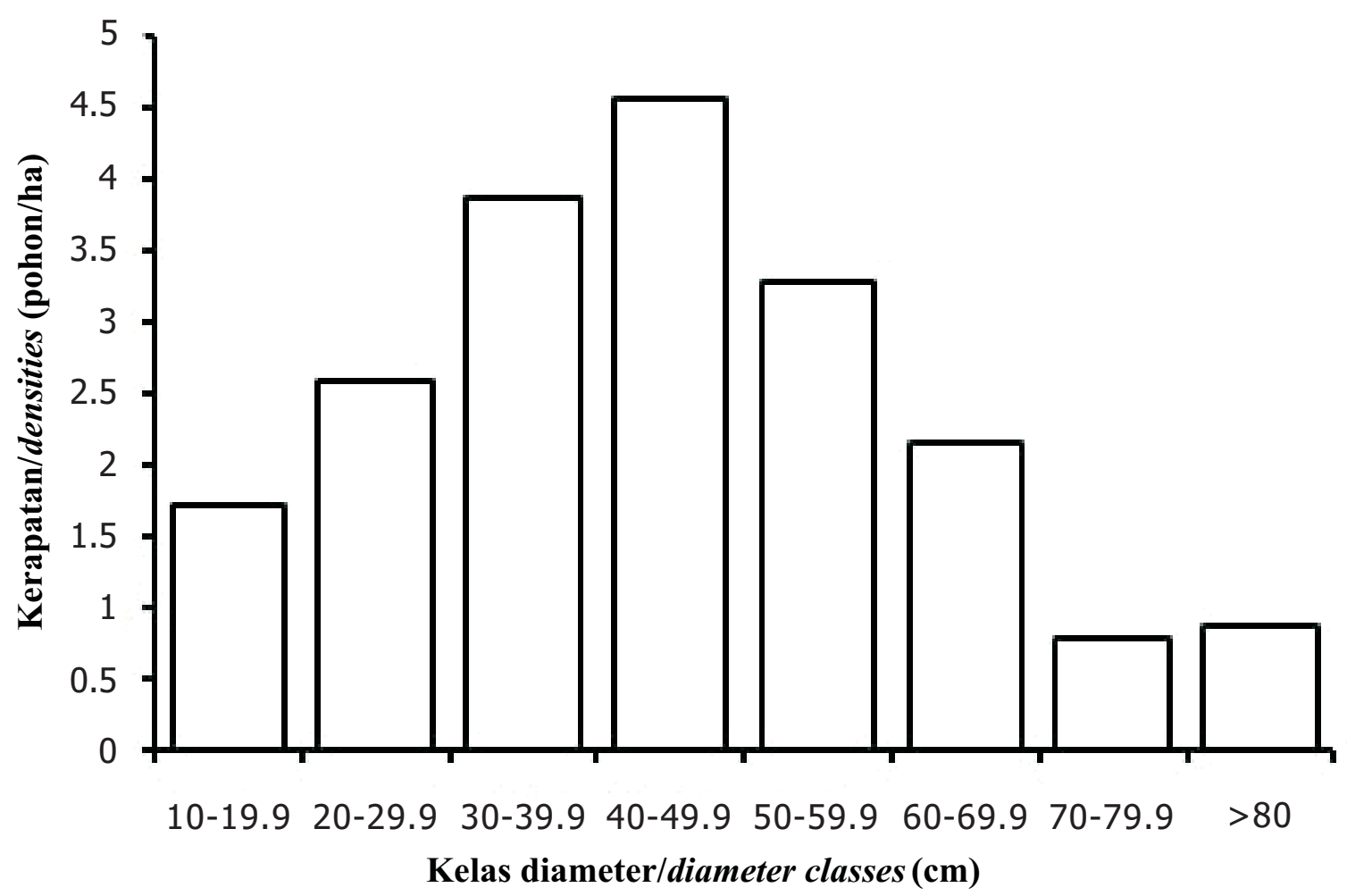

Gambar(Figure)3. Kerapatan pohon S. balangeran berdasarkan kelas diameter (Density of S. balangeran trees based on diameter classes)

Hasil penelitian menunjukkan bahwa berdasarkan kelas diameternya, pohon S. balangeran berdiameter menengah (30-39,9 cm, 40-49,9 cm dan 50-59,9 cm) memiliki kerapatan yang tertinggi yaitu berturut-turut 3,86 pohon/ha, 4,57 pohon/ha dan 3,29 pohon/ha. Selanjutnya kerapatannya cenderung menurun pada kelas diameter yang lebih rendah dan tinggi (Gambar 3). Hal ini menunjukkan bahwa pohon yang memasuki masa optimal menghasilkan buah memiliki kerapatan yang tinggi. Karena pada kelas diameter kecil masih dalam masa persiapan dan baru mulai berbunga atau berbuah, sedangkan pada diameter yang besar produktivitasnya sudah mulai menurun. 


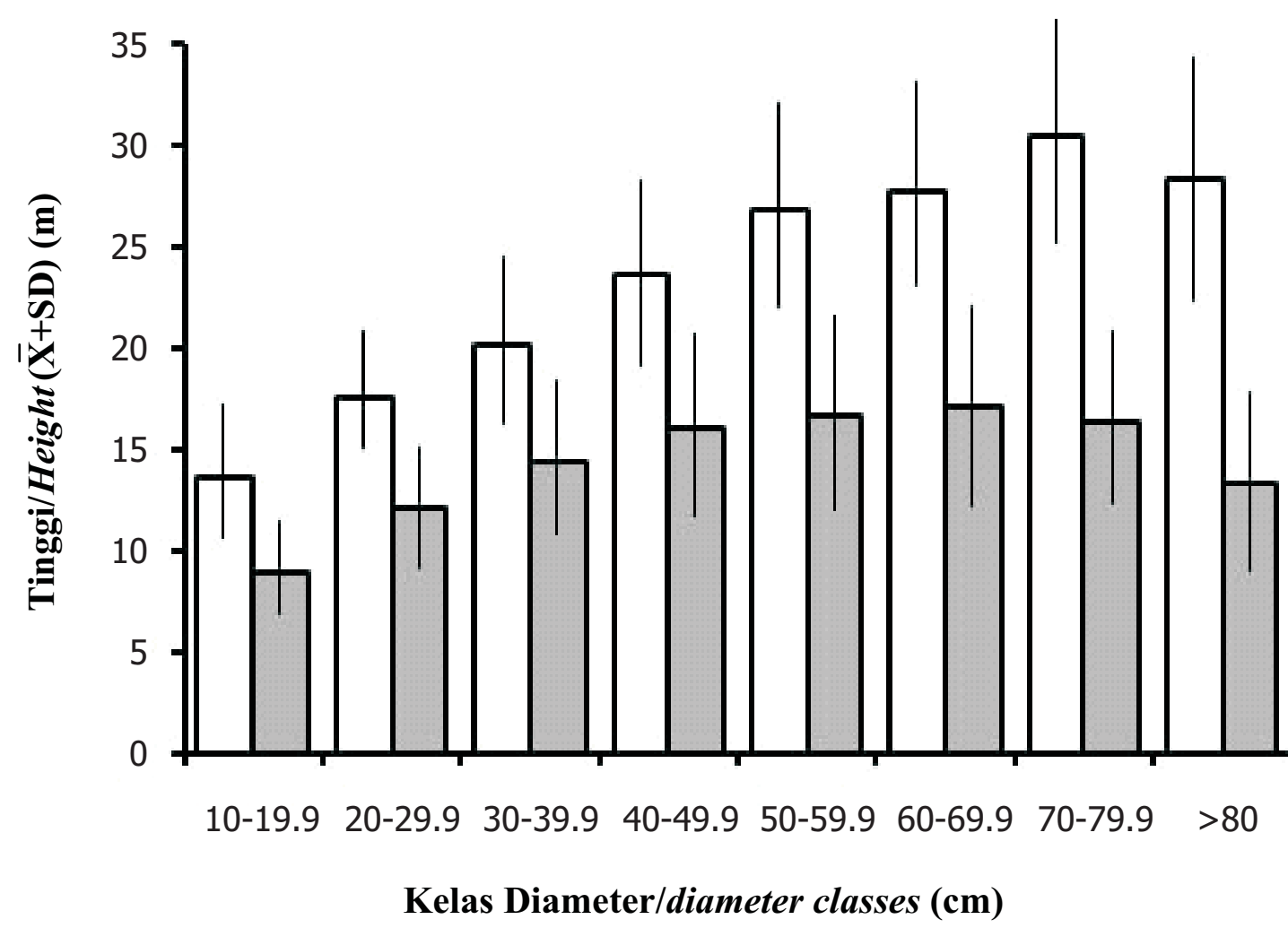

Gambar(Figure) 4. Tinggi pohon S. balangeran berdasarkan kelas diameter. Batang warna putih menunjukkan tinggi total, abu-abu menunjukkan tinggi bebas cabang. (Height of $\mathrm{S}$. balangeran trees based on diameter classes. White bars represent of total height, grey bars represent of branch free height)

Berdasarkan rata-rata tinggi hanya terdapat tiga strata tajuk yaitu stratum B $(30-40 \mathrm{~m})$, stratum C (20-30 m) dan stratum D (10-20 m) (Gambar 4). Pohon yang rata-rata tingginya menempati stratum $B$ adalah kelas diameter 70-79,9 cm, sebagian pohon juga menempati stratum C. Sedangkan pohon yang masuk dalam kelas diameter menengah sebagian besar menempati stratum C. Kondisi tersebut masih memberikan kesempatan yang besar kepada pohon yang berdiameter menengah untuk tajuknya mendapatkan cahaya matahari secara penuh. Dengan tajuk yang mendapat cahaya matahari secara penuh akan cepat merangsang pembungaan dan pembuahan. Menurut Smits (1986) pohon induk Dipterocarpaceae dapat berbuah saat tajuknya mendapatkan cahaya matahari penuh, sehingga tajuknya perlu menempati posisi dominan. Pohon dengan kondisi seperti ini umumnya sudah mencapai diameter $20-25 \mathrm{~cm}$. 


\section{KESIMPULAN DAN SARAN}

\section{A. Kesimpulan}

1. Shorea balangeran mendominansi vegetasi tingkat pohon, tiang dan semai di TBI Saka Kajang. Vegetasi tingkat pancang kehadiran S. balangeran rendah akibat pengambilan cabutan alam sebagai bibit dalam jumlah yang besar.

2. Penyebaran antar pohon di lokasi penelitian cenderung saling berdekatan pada areal yang terlalu kecil, sehingga kemungkinan terjadinya inbreeding sangat tinggi.

3. Pohon $S$. balangeran yang berdiameter batang besar $(\mathrm{dbh}>35)$ dijumpai di lokasi penelitian sebanyak $187(68 \%)$.

\section{B. Saran}

1. Perlu dilakukan seleksi pohon induk $S$. balangeran dengan kriteria fenotip yang baik dan jarak antar pohon induk 50-100 m.

2. Perlu dilakukan penjarangan agar tidak terjadi inbreeding.

3. Perlu dilakukan perluasan areal sumber benih. Lokasi penelitian ini yang berdekatan dengan TBI Saka Kajang II dapat menjadi alternatif areal perluasannya.

4. Perlu dilakukan pembatasan pengambilan cabutan anakan alam untuk menjaga sistem regenerasi pada sumber benih tetap berjalan dengan baik.

\section{UCAPAN TERIMA KASIH}

Ucapan terima kasih kepada Bpk. Arpin ketua KUD Kahimat yang telah menfasilitasi kegiatan di lapangan serta Zainal Arifin dan Warsidi yang telah membantu identifikasi dan pengumpulan data di lapangan. 


\section{DAFTAR PUSTAKA}

Ashton, P.S. 1982. Dipterocarpaceae. Flora Malesiana 9: 237-552.

Atmoko, T., Mukhlisi, Z. Arifin \& Warsidi. 2010. Potensi dan karakteristik floristik di TN Sebangau. Laporan penelitian. Balai Penelitian Teknologi Perbenihan Samboja.

BPTH Kalimantan, 2008. Database sumber benih Kalimantan. Balai Perbenihan Tanaman Hutan Kalimantan. Format Ms. Acces.

Daryono, H. 2006. Pemanfaatan lahan secara bijaksana dan revegetasi dengan jenis pohon tepat guna di lahan rawa gambut terdegradasi. Prosiding seminar hasil-hasil penelitian. Optimalisasi peran IPTEK dalam mendukung peningkatan produktifitas hutan dan lahan. Pusat Litbang Hutan dan Konservasi Alam. Bogor. pp.1-18.

Ditjen RLPS. 2004. Petunjuk teknis pembangunan dan pengelolaan sumber benih. Direktorat Perbenihan Tanaman Hutan. Direktorat Jenderal Rehabilitasi Lahan dan Perhutanan Sosial. Jakarta.

Djamhuri, E., Supriyanto, I. Z. Siregar, A. Sukendro, U. Y. Siregar, S. W. Budi, P. Pamungkas \& C. Wibowo. 2007. Petunjuk Teknis Seleksi Pohon Induk. Technical Report No 02/27. Departemen Silvikultur, Fakultas Kehutanan, Institut Pertanian Bogor.

Juliaty, N., D. Leppe \& W. Rusmantoro. 1998. Pengembangan dan pengelolaan tegakan benih. in: (eds) B.M. Purnama dan E. Jalaludin. Prosiding ekspose hasil-hasil penelitian Balai Penelitian Kehutanan Samarinda. Samarinda.

Martawijaya, A., I. Kartasujana. 1977. Ciri Umum, Sifat dan Kegunaan Jenis-jenis Kayu Indonesia. Lembaga Penelitian Hasil Hutan. Badan Penelitian dan Pengembngan Pertanian, Departemen Pertanian. Bogor. Publikasi Khusus No. 41.

Mueller-Dombois \& Ellenberg. 1974. Aims and methods of vegetation ecology. John Wiley and Sons, Inc. New York. pp. 118-120.

Newman, M.F., P.F. Burgues \& TC. Whitmore. 1999. Pedoman identifikasi pohon-pohon Dipterocarpaceae Pulau Kalimantan. Prosea Indonesia, Bogor. 
Ng, K. T.S., S. L. Lee, L. G. Saw, J. B. Plotkin \& C. L. Koh. 2006. Spatial structure and genetic diversity of three tropical tree species with different habitat preferences within a natural forest. Tree Genetics \& Genomes 2:121-131.

Omon, R.M. 1999. Pertumbuhan sepuluh jenis Dipterokarpa di areal Hutan Tanaman Industri PT Inhutani I, Batu Ampar Mentawir, Balikpapan, Kalimantan Timur. Bulletin Penelitian Kehutanan. Balai Penelitian Kehutanan Samarinda. Vol. 14.

Phillips, V.D. 1998. Peatswamp ecology and sustainable development in Borneo. Biodiversity and Conservation 7:651-671.

Saribi, A.H. \& S. Riswan. 1997. Peat swamp forest in Nyaru Menteng Arboretum, Palangkaraya, Central Kalimantan, Indonesia: Its tree species diversity and secondary succession. Paper presented on the Seminar on Tropical Ecology held by Japan Society of Tropical Ecology 21-22 June 1997, Shiga, Japan.

Schmidt, L. 2000. Panduan penanganan benih tanaman hutan tropis dan sub tropis (Guide to Handling of Tropical and Subtropical Forest Seed). Ditjen. Rehabilitasi Lahan dan Perhutanan Sosial. Departemen Kehutanan. Jakarta. p: 37-38.

Siregar, M. \& E.N. Sambas. 2000. Floristic Composition of Peat Swamp Forest in MensematSambas, West Kalimantan. Proceedings of the International Symposium on Tropical Peatlands. Hokkaido University \& Indonesian Institute of Sciences. pp. 153-164.

Soerianegara, I. \& A. Indrawan. 1988. Ekologi Hutan. Fakultas Kehutanan Institut Pertanian Bogor. Bogor.

Smits, W. T. M. 1986. Pedoman sistem cabutan bibit Dipterocarpaceae. Balai Penelitian Kehutanan Samarinda. Samarinda.

Yasman, I. 1994. Dasar-dasar pengenalan anakan Dipterocarpaceae. Balai Penelitian Kehutanan Samarinda. Samarinda. (Edisi khusus). No. 10: 1-23.

Yusuf, R. 1999. Komposisi, Struktur vegetasi dan degradasi jenis pada hutan sekunder setahun setelah kebakaran di kawasan Taman Nasional Tanjung Puting, Kalimantan Tengah. Paper 
JURNAL PENELITIAN DIPTEROKARPA

Vol.5 No.2, Desember 2011

presented in Seminar of Biodiversitas dan Pengelolaan Hutan Gambut Secara Berkelanjutan, Bogor, 12 Februari 1999. 